\title{
Vitamin C deficiency: more than just a nutritional disorder
}

\author{
Joris R. Delanghe $\cdot$ Michel R. Langlois • \\ Marc L. De Buyzere $\cdot \mathrm{Na} \mathrm{Na} \cdot$ Jin Ouyang $\cdot$ \\ Marijn M. Speeckaert $\cdot$ Mathieu A. Torck
}

Received: 24 March 2011/Accepted: 10 May 2011/Published online: 26 May 2011

(c) Springer-Verlag 2011

\begin{abstract}
Although vitamin C deficiency and scurvy are generally considered as pure nutritional disorders, only a minority of the vitamin $\mathrm{C}$ concentration is determined by food intake. In the presence of transition metals (iron and copper), the antiscorbutic factor shifts from an antioxidant to a pro-oxidant function. Haptoglobin $(\mathrm{Hp})$ is a plasma $\alpha-2$ glycoprotein characterized by 3 common phenotypes (Hp 1-1, Hp 2-1 and Hp 2-2). Its free hemoglobin (Hb)-binding capacity prevents $\mathrm{Hb}$-driven oxidative damage. When the antioxidant capacity of $\mathrm{Hp}$ is insufficient, its
\end{abstract}

\footnotetext{
J. R. Delanghe · M. R. Langlois · M. M. Speeckaert

Department of Clinical Chemistry, University Hospital Ghent,

De Pintelaan 185, B 9000 Ghent, Belgium

e-mail: Michel.Langlois@azsintjan.be

M. M. Speeckaert

e-mail: Marijn.Speeckaert@ugent.be

M. R. Langlois · M. L. De Buyzere

Department of Cardiovascular Diseases, University Hospital

Ghent, De Pintelaan 185, B 9000 Ghent, Belgium

e-mail: Marc.DeBuyzere@ugent.be

N. Na $\cdot$ J. Ouyang

Department of Chemistry, Beijing Normal University,

No. 44, Beijing 100875, China

e-mail:nan05@mails.tsinghua.edu.cn

J. Ouyang

e-mail: jinoyang@bnu.edu.cn

M. A. Torck

Department Languages and Cultures of South and East Asia Ghent University, Blandijnberg 2, B 9000 Ghent, Belgium

e-mail: Mathieu.Torck@ugent.be

J. R. Delanghe $(\bowtie)$

Laboratory Clinical Chemistry 2P8, Ghent University Hospital, De Pintelaan 185, 9000 Ghent, Belgium

e-mail: Joris.Delanghe@ugent.be
}

role is taken over by hemopexin (heme-binding protein) and by vitamin $\mathrm{C}$ (free radical scavenger). The Hp 2-2 phenotype has a lower capacity to inhibit oxidation and vitamin $\mathrm{C}$ depletion. In this article, two consequences of this major finding are tackled. The Hp polymorphism is an important non-nutritional modifying factor in the pathogenesis of vitamin $\mathrm{C}$ deficiency and scurvy, which may explain the success of long-range human migration by the natural selection of some populations characterized by high Hp 1 allele frequencies. Moreover, we propose tailoring the recommended dietary allowance (RDA) values of vitamin $\mathrm{C}$, taking into consideration the Hp phenotype dependency.

Keywords Haptoglobin · Polymorphism - Scurvy · Vitamin C

Due to the lack of L-gulonolactone oxidase, human is one of the few species not capable of synthesizing the chemically instable ascorbic acid (vitamin C) (Chatterjee et al. 1961). This mutational loss, which probably took place in a remote primate ancestor of man (Gluecksohn-Waelsch 1963), causes a dependency on dietary vitamin C sources, but can also be considered as an advantage since ascorbic acid synthesis requires a lot of costly glucose reserves. On average, the human body loses approximately $3 \%$ of its vitamin $\mathrm{C}$ content per day, which is the percentual daily loss corresponding with the first-order elimination process of vitamin $\mathrm{C}$ assuming no intake. This severely limits the disease-free and survival time when subjects are on a diet poor in vitamin $\mathrm{C}$, because this nutrient is a first-line antioxidant acting as a free radical scavenger. The half-life of ascorbic acid is approximately 16 days (Yung et al. 1978). In subjects without vitamin $C$ intake, ascorbic acid is no longer detected in blood after 35-40 days 
(Willet 1998). In 1939, a Harvard surgeon deliberately went on to a $\mathrm{C}$-free diet, and although his blood vitamin level dropped rapidly, it was only after 12 weeks that he began to have feelings of fatigue (Crandon et al. 1940). In a larger British trial during World War II, it took 17-20 weeks for any signs to appear among 120 volunteers (No authors listed 1948). In a later trial using 4 American prisoners, using a purified liquid diet, skin changes appeared after 8-13 weeks and gum changes in 5-27 weeks (Hodges et al. 1969). So, the clinical symptoms due to vitamin $\mathrm{C}$ deficiency develop very slowly. Beside the conflicting results of the therapeutic use of ascorbic acid in a wide range of diseases (Cahill and El-Sohemy 2010), vitamin C deficiency and scurvy have always been a major health problem. The in vivo instability of this antiscorbutic factor is due to its proneness to oxidation. Although scurvy is generally regarded as a nutritional problem, only $\pm 17 \%$ of the variance of the serum vitamin $\mathrm{C}$ concentration can be explained by vitamin $\mathrm{C}$ intake, as presented in the Third National Health and Nutrition Examination Survey. The influence of dietary vitamin $\mathrm{C}$ on serum ascorbic acid measurements in this study was complicated by the use of food frequency questionnaires that poorly report vitamin C levels (Hampl et al. 2004).

Several in vivo factors related to inflammation and oxidative stress have been demonstrated to influence the biological variation in vitamin $C$ concentration in humans. Recent research showed that genetic polymorphisms coding for vitamin C transporter protein (SVCT) 1 (SLC23A1 gene) (Cahill and El-Sohemy 2009) and glutathione S-transferase (GST) (Cahill et al. 2009) may affect the concentrations of fasting serum ascorbic acid independent of diet. SVCT1 and SVCT2 genotypes modify the strength of the correlation between dietary vitamin $\mathrm{C}$ and serum ascorbic acid (Cahill and El-Sohemy 2009). GST enzymes have a protective capacity against vitamin $\mathrm{C}$ deficiency when dietary vitamin C is insufficient (Cahill et al. 2009). Another important factor, the acute phase protein haptoglobin $(\mathrm{Hp})$ is characterized by a genetic polymorphism with three phenotypes (Hp 1-1, Hp 2-1, and Hp 2-2), which results from the expression of two alleles (Hp 1 and Hp 2) of the Hp gene on chromosome 16q22. The major biological function of $\mathrm{Hp}$ is binding and recycling of free hemoglobin $(\mathrm{Hb})$ in plasma to prevent oxidative damage induced by heme iron following hemolysis (Langlois and Delanghe 1996). When the Hb-binding capacity of $\mathrm{Hp}$ is saturated, its antioxidant role is taken over by hemopexin (heme-binding protein) and by vitamin $\mathrm{C}$.

Hp phenotypes show important structural and functional differences. Hp $1-1$ is a small dimeric protein $(86 \mathrm{kDa})$, whereas Hp 2-1 and Hp 2-2 show polymeric forms (up to $900 \mathrm{kDa}$ ). Iron status is affected by Hp polymorphism as
$\mathrm{Hp} \mathrm{2-2}$ is less efficient in the clearance of $\mathrm{Hb}$ from the circulation. As a consequence, Hp 2-2 individuals show iron retention in macrophages and present higher serum iron and ferritin concentrations and increased transferrin saturation compared with the other $\mathrm{Hp}$ phenotypes (Langlois et al. 2000).

The iron delocalization pathway, selectively occurring in Hp 2-2 subjects, has important biological consequences. Iron withholding is an important example of nutritional immunity in the defense against infectious diseases (Weinberg 1984; Kristiansen et al. 2001). Hp acts as a natural bacteriostat by preventing the utilization of $\mathrm{Hb}$ by pathogenic bacteria which require iron for their growth. The iron-restrictive environment in body fluids established by $\mathrm{Hp}-\mathrm{Hb}$ binding is part of the non-specific defense against bacterial invasion. Hp polymorphism plays a role in a number of bacterial and viral infections (Kasvosve et al. 2010). In the early history of mankind, a successful mutation took place, which proved to be beneficial in terms of conservation of iron, although it had a major impact on vitamin C stability in vivo (Kamel and 'Umar 1975).

Nowadays, scurvy is still classified as a nutritional disorder or avitaminosis instead of a genetic disease. In humans, the vitamin $\mathrm{C}$ status is not only determined by diet but also by the environment, lifestyle, biological and pathological conditions (Langlois et al. 2009; Pincemail et al. 2011; Lowik et al. 1993; Galan et al. 2005; Vioque et al. 2007; Johnston et al. 2006). In this paper, we will focus on the link between the vitamin $\mathrm{C}$ status and the Hp polymorphism by discussing the three following hypotheses:

(1) The stability of vitamin $\mathrm{C}$ depends on the iron status and the Hp polymorphism.

(2) Success of long-range human migration has been strongly determined by Hp polymorphism. Due to natural selection, some populations characterized by high Hp 1 allele frequencies are much less prone to scurvy.

(3) The recommended dietary allowance (RDA) values of vitamin $\mathrm{C}$ might be strongly Hp phenotype dependent.

Scurvy is one of the genetic metabolic anomalies that has been with us since prehistory, as it was already reported by the Egyptians (1550 BC) and Hippocrates (460 BC-380 BC) (Hirsch 1885; Bourne 1949; Carpenter 1986). In his Handbook of geographical and historical pathology, Hirsch described in detail the scurvy outbreaks among Europeans between 1556 and 1873 (the expedition by Cartier in the sixteenth century, the Dutch expedition to Novaya Zemlya (1594-1596), the US Army outpost Fort Atkinson in 1819, Perth prison in the nineteenth century) (Langlois et al. 2009; Delanghe et al. 2007). Nutritional availability of ascorbic acid is geographically dependent. 
Although relative losses by scurvy were relatively lower in Europe, it is clear that the majority of described scurvy outbreaks were situated in Europe. However, there is a strong geographical bias in this description. A particular susceptibility of East and South East Asians toward scurvy has been reported (Delanghe 2007; Hirsch 1885; Torck 2005; Torck 2009). A medical report from the eighteenthcentury documenting outbreaks in Chinese army garrisons operating in the north of the country mentions rates of affected troops amounting to 80 and 90\% (Torck 2009). Furthermore, Japanese sailors were particularly susceptible to scurvy during drifting accidents in the Pacific. Among castaways, mortality rates as high as 50 and $78 \%$ have been reported in nineteenth-century records (Delanghe et al. 2007). Moreover, in early modern Japan (nineteenth century), there is a description of the Tsugaru soldiers with up to $72 \%$ mortality from scurvy (Walker 1999; Matsuki 1981). It is important to point out that these occurrences date back to a time frame in the context of which the diet of the Japanese population is generally considered to be nutritionally balanced, stable, and thus, in quality not likely to be inferior to contemporary European diets (Hanley 1991)

Although the scorbutic syndrome has been merely regarded as a pure nutritional disturbance, differences in Hp phenotype distribution may offer a plausible explanation for these historical findings, which are furthermore supported by solid in vitro and in vivo biochemical evidence (Delanghe et al. 2007). In human evolution, the Hp 2 allele originated in South Asia, which explains the highest Hp 2 and the lowest wild-type Hp 1 allele $(\sim 0.25)$ frequencies in the local population (Fig. 1). The human species is currently in a state of transient gene equilibrium, in which the mutant Hp 2 allele has been generally favored during evolution. Among Western European populations, Hp 1 and Hp 2 allele frequencies are $\sim 0.40$ and 0.60, respectively (Langlois and Delanghe 1996). However, there are some regions where populations can be found presenting with high $\mathrm{Hp} 1$ allele frequencies (Table 1), e.g., the indigenous populations of Latin America (Hp 1 allele frequency: 0.58-0.78). Amerind populations showing very high $\mathrm{Hp} 1$ allele frequencies amazingly proved to be capable of crossing the ocean on simple rafts without any advanced shipbuilding knowledge or technology (Heyerdahl 1995). The advantage of Hp 1-1 as a genetic factor favoring survival in long-distance sea voyages is illustrated by the Hp phenotype distribution among the indigenous populations of remote islands. Easter Island is one of the remotest places on earth. Its indigenous Rapa Nui population is characterized by the highest Hp 1 allele frequency (0.86) known (Delanghe et al. 2007). Undoubtedly, early immigrants of Easter Island and Northern Canada have been subject to a challenging vitamin $\mathrm{C}$ depletion (scurvy) during the long voyage. Documents from the eighteenth and nineteenth centuries indicate that scurvy caused by vitamin $\mathrm{C}$ deficiency was not observed among the Inuit in contrast to a serious illness observed among Arctic explorers (Fediuk 2000). Madagascar has a mixed population of African and proto-Indonesian origin. The Hp 1 allele frequency of the island's population is remarkably higher than the one of the constituting founding populations, which is pleading for a genetic selection based on $\mathrm{Hp}$ phenotype during the migration (Buettner-Janusch et al. 1973). Finally, in the Awyu population of Papua New Guinea, which is also characterized by a predominance of the Hp 1 allele, no events of scurvy have been reported. In this area, the regions with the highest $\mathrm{Hp} 1$ allele frequency $(>0.85)$ are Frederik Hendrik Island (West Irian) and the region north of it, which is a big contrast in $\mathrm{Hp}$ allele frequencies with the aboriginals from Northern Australia. Looking at the other gene maps of New Guinea, there is no similar gradient. Hp polymorphism seems to be an independent genetic factor (Klein 1954; Hill et al. 1986; Cavalli-Sforza et al. 1994).

Based on those findings, the effect of Hp polymorphism upon vitamin $\mathrm{C}$ metabolism offers a plausible, though speculative explanation how during the course of human history, some populations characterized by a high $\mathrm{Hp} 1$ allele frequency have been able to migrate successfully over long distances and can survive on a vitamin $\mathrm{C}$ poor diet (Delanghe et al. 2007). This suggestion is further supported by the results of the Toronto Nutrigenomics and Health Study. In this study, Cahill and El-Sohemy showed a gene-diet interaction on the serum ascorbic acid concentration. In contrast to carriers of the $\mathrm{Hp} 1$ allele with a greater antioxidant capacity, Hp 2-2 subjects had an increased risk of deficiency if they did not meet the RDA for vitamin C (Cahill and El-Sohemy 2010). Hp acts to prevent the oxidative and toxic effects of the iron-containing heme in $\mathrm{Hb}$ ( $\mathrm{Na}$ et al. 2005). The ascorbic acid stability in body fluids is lower in $\mathrm{Hp} \mathrm{2-2} \mathrm{individu-}$ als (Cahill and El-Sohemy 2010; Delanghe et al. 2007; Sadrzadeh and Eaton 1988; Langlois et al. 1997). Hp 2-2 subjects are less efficient in removing free $\mathrm{Hb}$ from the plasma, which may favor an iron-mediated vitamin $\mathrm{C}$ depletion (Langlois et al. 1997; Delanghe and Langlois 2002). Furthermore, the ability of $\mathrm{Hp} \mathrm{2-2} \mathrm{polymers} \mathrm{to}$ sieve into the extravascular compartment is restricted by their high molecular mass. Parts of $\mathrm{Hb}$-derived iron are delocalized and accumulated in inert, poorly accessible iron storage compartments (Delanghe et al. 2007). Complexes of $\mathrm{Hb}$ and multimeric $\mathrm{Hp}$ 2-2 exhibit a higher affinity for the $\mathrm{Hb}$ scavenger receptor CD163, which accounts for a substantial transfer of iron into macrophages, than complexes of $\mathrm{Hb}$ and the $\mathrm{Hp} 1-1$ phenotype do (Kristiansen et al. 2001). Iron loading of macrophages 
Fig. 1 Map of Hp1 allele frequency. The numbers represent the $\mathrm{Hp} 1$ allele frequency (as a percentage). The arrows represent the direction of human migration in pre-historical times. Four exceptions on the normal $\mathrm{Hp}$ allele distribution with extremely high $\mathrm{Hp} 1$ allele frequencies are found around the Hudson Bay, Easter Island, Madagascar, and Papua New Guinea [Frederik Hendrik Island (West Irian)]

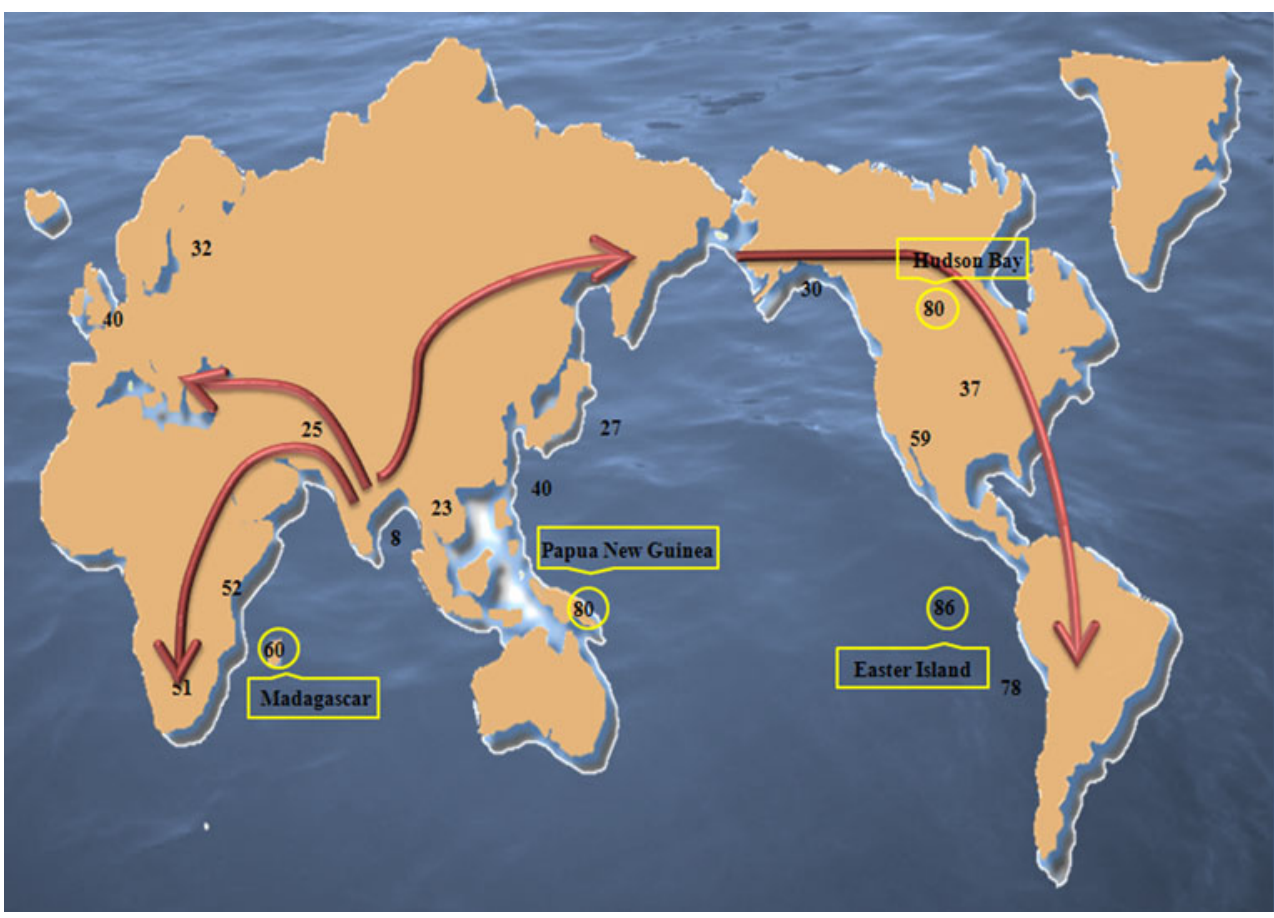

Table 1 List of areas/populations with a high Hp 1 allele frequency and its relationship to the incidence of scurvy

\begin{tabular}{lll}
\hline & $\begin{array}{l}\text { Hp 1 allele } \\
\text { frequency }\end{array}$ & Comment \\
\hline Easter Island (Rapa Nui) & 0.86 & Very remote place (Delanghe et al. 2007) \\
$\begin{array}{l}\text { Hudson Bay (Inuit) } \\
\text { Madagascar }\end{array}$ & 0.80 & $\begin{array}{c}\text { Extremely low vitamin C intake (10 mg/day) (Fediuk 2000) } \\
\text { Papuna New Guinea (Awyu) }\end{array}$ \\
\hline
\end{tabular}

results in iron-driven oxidative stress, which is reflected by lower serum vitamin $\mathrm{C}$ concentrations in $\mathrm{Hp} 2-2$ subjects (Delanghe and Langlois 2002). No difference in renal threshold and urinary excretion of ascorbic acid is observed between Hp phenotypes (Langlois et al. 1997).

According to the guidelines of the Food and Nutrition Board, the RDA for vitamin $\mathrm{C}$, which is the amount considered to maintain normal nutrition in the general population, is $90 \mathrm{mg} /$ day for men and $75 \mathrm{mg} /$ day for women. These data have been derived from a population, mainly consisting of Europeans and Afro-Americans. For smokers, the daily amount of vitamin $\mathrm{C}$ has to be increased with $35 \mathrm{mg} /$ day (Food et al. 2000). However, based on the findings mentioned earlier, the influence of the Hp polymorphism on the vitamin $\mathrm{C}$ need should be taken into account. Research learns that the diet of the Inuit in the Hudson Bay (a region with a predominance of the Hp 1 allele) was mainly composed of animal sources, generally perceived as poor sources of vitamin C. It is assumed that the Inuit were able to obtain a minimum level of vitamin $\mathrm{C}$ (10 mg/day) from a diet of frozen/raw, fermented, and dried animal food, required to prevent scurvy (Fediuk 2000). As the stability of ascorbic acid is lower in Hp 2-2 individuals, the required daily intake of this nutrient is higher compared with the other Hp phenotypes (Cahill and El-Sohemy 2010; Delanghe et al. 2007; Langlois et al. 1997; Delanghe and Langlois 2002). Better tailored RDA guidelines for ascorbic acid taking into account the ethnical background could therefore contribute to a better nutritional health policy.

\section{Conclusions}

The classical view of vitamin $\mathrm{C}$ deficiency and scurvy being exclusively nutritional disorders needs to be tailored. Clinical and in vitro studies have demonstrated that the genetic polymorphism of the abundant plasma protein 
haptoglobin (Hp) may play an important role. This finding has major consequences in a number of medical problems. It provides a new rationale to intriguing historical questions, e.g., it may give evidence for the thesis that $\mathrm{Hp}$ polymorphism is an important non-nutritional modifying factor in the pathogenesis of vitamin $\mathrm{C}$ deficiency and scurvy. These approaches may result in a better tailored treatment for diseases in which the redox state of the patient plays a role.

Conflict of interest There are no commercial or financial interests involved in this work.

\section{References}

Bourne GH (1949) Vitamin C and immunity. Br J Nutr 2:341-346 Buettner-Janusch J, Reisman R, Coppenhaver D, Mason GA, Buettner-Janusch V (1973) Transferrins, haptoglobins, and ceruloplasmins among tribal groups of Madagascar. Am J Phys Anthropol 38:661-669

Cahill LE, El-Sohemy A (2009) Vitamin C transporter gene polymorphisms, dietary vitamin $\mathrm{C}$ and serum ascorbic acid. J Nutrigenet Nutrigenomics 2:292-301

Cahill LE, El-Sohemy A (2010) Haptoglobin genotype modifies the association between dietary vitamin $\mathrm{C}$ and serum ascorbic acid deficiency. Am J Clin Nutr 92:1494-1500

Cahill LE, Fontaine-Bisson B, El-Sohemy A (2009) Functional genetic variants of glutathione S-transferase protect against serum ascorbic acid deficiency. Am J Clin Nutr 90:1411-1417

Carpenter KJ (1986) The history of scurvy and vitamin C. Cambridge University Press, Cambridge

Cavalli-Sforza LL, Menozzi P, Piazza A (1994) The history and geography of human genes. Princeton University Press, Princeton

Chatterjee IB, Kar NC, Ghosh NC, Guha BC (1961) Aspects of ascorbic acid biosynthesis in animals. Ann NY Acad Sci 92:36-56

Crandon JH, Lund CC, Dill DB (1940) Experimental human scurvy. N Engl J Med 223:353-369

Delanghe JR, Langlois MR (2002) Haptoglobin polymorphism and body iron stores. Clin Chem Lab Med 40:212-216

Delanghe J, Langlois M, De Buyzere M, Torck M (2007) Vitamin C deficiency and scurvy are not only a dietary problem but are codetermined by the haptoglobin polymorphism. Clin Chem 53:1397-1400

Fediuk K (2000) Vitamin C and the Inuit diet: past and present. MSc thesis. McGill University, Montreal

Food and Nutrition Board, Institute of Medicine (2000) Dietary reference intakes for vitamin $\mathrm{C}$, vitamin $\mathrm{E}$, selenium, and carotenoids. Areport of the panel on dietary antioxidants and related compounds, subcommittees on upper reference levels of nutrients and interpretation and uses of dietary reference intakes, and the standing committee on the scientific evaluation of dietary reference intakes. National Academy Press, Washington

Galan P, Viteri FE, Bertrais S, Czernichow S, Faure H, Arnaud J, Ruffieux D, Chenal S, Arnault N, Favier A, Roussel AM, Hercberg S (2005) Serum concentrations of $\beta$-carotene, vitamins $\mathrm{C}$ and $\mathrm{E}$, zinc and selenium are influenced by sex, age, diet, smoking status, alcohol consumption and corpulence in a general French adult population. Eur J Clin Nutr 59:1181-1190

Gluecksohn-Waelsch S (1963) Lethal genes and analysis of differentiation. Science 142:1269-1276
Hampl JS, Taylor CA, Johnston CS (2004) Vitamin C deficiency and depletion in the United States: the Third national health and nutrition examination survey, 1988 to 1994. Am J Public Health 94:870-875

Hanley SB (1991) Tokugawa society: material culture, standard of living, and life-styles. In: Whitney Hall J, McClain JL (eds) The Cambridge history of Japan, Vol 4: early modern Japan. Cambridge University Press, Cambridge, pp 660-705

Heyerdahl T (1995) Tucume and the maritime heritage of Peru's North Coast. In: Heyerdahl T, Sandweiss DH, Narvaez A (eds) Pyramids of Tucume: the quest for Peru's forgotten city. Thames and Hudson, London, pp 9-37

Hill AV, Bowden DK, Flint J, Whitehouse DB, Hopkinson DA, Oppenheimer SJ, Serjeantson SW, Clegg JB (1986) A population genetic survey of the haptoglobin polymorphism in melanesians by DNA analysis. Am J Hum Genet 38:382-389

Hirsch A (1885) Handbook of geographical and historical pathology, vol II. The New Sydenham Society, London

Hodges RE, Baker EM, Hood J, Sauberlich HE, March SC (1969) Experimental scurvy in man. Am J Clin Nutr 22:535-548

Johnston CS, Corte C, Swan PD (2006) Marginal vitamin C status is associated with reduced fat oxidation during submaximal exercise in young adults. Nutr Metab (Lond) 3:35. doi: 10.1186/1743-7075-3-35

Kamel K, 'Umar M, Ibrahim W, Mansour A, Gaballah F, Selim O, Azim A, Hamza S, Sabry F, Moafy N, El-naggar A, Hoerman K (1975) Anthropological studies among Libyans. Erythrocyte genetic factors, serum haptoglobin phenotypes and anthropometry. Am J Phys Anthropol 43:103-111

Kasvosve I, Speeckaert MM, Speeckaert R, Masukume G, Delanghe JR (2010) Haptoglobin polymorphism and infection. Adv Clin Chem 50:23-46

Klein WC (1954) De ontwikkeling op economisch, sociaal en cultureel gebied in Nederlands en Australisch Nieuw-Guinea. Deel III. Staatsdrukkerij- en Uitgeverijbedrijf's-Gravenhage,'sGravenhage

Kristiansen M, Graversen JH, Jacobsen C, Sonne O, Hoffman HJ, Law SK, Moestrup SK (2001) Identification of the haemoglobin scavenger receptor. Nature 409:198-201

Langlois M, Delanghe J (1996) Biological and clinical significance of haptoglobin polymorphism in humans. Clin Chem 42:1589-1600

Langlois MR, Delanghe JR, De Buyzere ML, Bernard D, Ouyang J (1997) Effect of haptoglobin on the metabolism of vitamin C. Am J Clin Nutr 66:606-610

Langlois MR, Martin ME, Boelaert JR, Beaumont C, Taes YE, De Buyzere ML, Bernard DR, Neels HM, Delanghe JR (2000) The haptoglobin 2-2 phenotype affects serum markers of iron status in healthy males. Clin Chem 46:1619-1625

Langlois MR, De Buyzere ML, Delanghe JR (2009) Plasma vitamin C for predicting cardiovascular disease: more than a nutritional biomarker. Acta Clin Belg 64:341-343

Lowik MR, Hulshof KF, Schneijder P, Schrijver J, Colen AA, van Houten P (1993) Vitamin C status in elderly women: a comparison between women living in a nursing home and women living independently. J Am Diet Assoc 93:167-172

Matsuki A (1981) Prevalence of scurvy among soldiers of the Hirosake clan in Yezo area. Nippon Ishigaku Zasshi 27:56-63

Na N, Ouyang J, Taes YE, Delanghe JR (2005) Serum free hemoglobin concentrations in healthy individuals are related to haptoglobin type. Clin Chem 51:1754-1755

No authors listed (1948) Vitamin C subcommittee of the medical research council. Vitamin $\mathrm{C}$ requirement of human adults. Lancet 1:853-858

Pincemail J, Vanbelle S, Degrune F, Cheramy-Bien JP, Charlier C, Chapelle JP, Giet D, Collette G, Albert A, Defraigne JO (2011) Lifestyle behaviours and plasma vitamin $\mathrm{C}$ and $\beta$-carotene levels 
from the ELAN population (Liège, Belgium). J Nutr Metab [Epub ahead of print]

Sadrzadeh SMH, Eaton JW (1988) Hemoglobin-mediated oxidant damage to the central nervous system requires endogenous ascorbate. J Clin Invest 82:1510-1515

Torck M (2005) The issue of food provision and scurvy in East and West: a comparative enquiry into medieval knowledge of provisioning, medicine and seafaring history. In: Schottenhammer A (ed) East Asian maritime history I: trade and transfer across the East Asian "Mediterranean". Harrassowitz Verlag, Wiesbaden, pp 275-288

Torck M (2009) Avoiding the Dire Straits: an inquiry into food provisions and scurvy in the maritime and miltary history of China and wider East Asia. Harrassowitz Verlag, Wiesbaden
Vioque J, Weinbrenner T, Asensio L, Castello A, Young IS, Fletcher A (2007) Plasma concentrations of carotenoids and vitamin C are better correlated with dietary intake in normal weight than overweight and obese elderly subjects. Br J Nutr 97:977-986

Walker BL (1999) The early modern Japanese state and Ainu vaccinations: redefining the body politic 1799-1868. Past and Present 163:121-160

Weinberg ED (1984) Iron withholding: a defense against infection and neoplasia. Physiol Rev 64:65-102

Willet W (1998) Nutritional epidemiology, 2nd edn. Oxford University Press, New York

Yung S, Mayersohn M, Robinson JB (1978) Ascorbic acid elimination in humans after intravenous administration. J Pharm Sci 67:1491-1492 